\title{
Influence of Audit Committee Industry Expertise on Internal Audit
}

\author{
Abdulaziz Alzeban ${ }^{1}$ \\ ${ }^{1}$ King Abdulaziz University, Saudi Arabia \\ Correspondence: Abdulaziz Alzeban, King Abdulaziz University, Saudi Arabia. E-mail: aziztheban@yahoo.com
}

Received: January 15, 2015

Accepted: February 5, 2015

Online Published: March 27, 2015

doi:10.5539/ijbm.v10n4p26

URL: http://dx.doi.org/10.5539/ijbm.v10n4p26

\begin{abstract}
Practitioners argue that audit committee effectiveness is improved when committee members have industry expertise, yet the focus by regulators and researchers to date has been on the contribution made by members with accounting and auditing expertise. This study examines whether internal audit characteristics is indeed greater when audit committee members have industry expertise combined with auditing expertise. Data from a survey of 64 chief internal auditors from companies registered on the Saudi Stock Exchange TADAWL, provides results that suggest that when audit committee members possess both industry expertise and auditing expertise, the committee's role in improving the quality of internal audit is enhanced. This outcome is concluded as one that can be generalised beyond the Saudi Arabian context.
\end{abstract}

Keywords: internal audit characteristics, audit committee, industry expertise, auditing experts

\section{Introduction}

The study aims to explore the influence of audit committee industry expertise on internal audit characteristics (IAC) since it may be the case that irrespective of other qualities, such as greater authority, independence, and financial expertise, audit committees might still fall short in their appreciation of industry, and be unable to grasp, and therefore, adequately monitor, complicated auditing issues in particular industrial contexts. For instance, experience in retail might help audit committees to ensure that companies make an appropriate write-down of inventory in instances where obsolescence in the product range is likely. Likewise, revenue recognition which is an important area within accounting (Beasley et al., 2010; Beasley et al., 2000), requires an appreciation of the earnings process and that in itself is part of a company's overall business processes, which in themselves are usually specific to the industry in which the company operates.

Consequently, the value of audit committee members with such industry expertise is acknowledged by practitioners. Olson (1999) for instance, observes that it is audit committee members with actual management experience and industry knowledge who are most qualified for the job, rather than those who come from backgrounds in accounting or auditing. Likewise, Deloitte Development (2010) makes the observation that as the main function of the audit committee is to identify and deal with accounting and financial reporting risks, the typical audit committee is largely composed of individuals with finance, accounting, or legal backgrounds, but that there is a genuine case for introducing other specialists in order to bring knowledge of company or industry complexities.

Nonetheless, such comments regarding the value of industry expertise among audit committee members (Bédard \& Gendron, 2010; DeZoort et al., 2002), have not stimulated research into the relationship between audit committee industry expertise and IAC, and it is this absence of interest that provides the initial drive to conduct this study which aims to make a contribution to the literature regarding the influence of such expertise in enabling audit committees to perform their duties diligently and effectively.

This contribution occurs in a number of ways. Firstly, with only a few exceptions, the literature to date has concentrated on the financial expertise of audit committee members. Cohen et al. (2014) stand out in this respect, as they do consider the influence of industry expertise on the audit committee's ability to monitor the financial reporting. Likewise, Carcello and Neal (2003) place their focus on audit committees with governance expertise, and Krishnan et al. (2011) examine audit committees with legal expertise. However, much of the other research explores the financial expertise of audit committees (Naiker et al., 2013; Carcello et al., 2011a; Carcello et al., 2011b; Dhaliwal et al., 2010; Hoitash \& Hoitash, 2009; Krishnan \&Visvanathan, 2008; Abbott et al., 2003; Carcello et al., 2002). It is believed, therefore, that this paper is the first to investigate the role played by a 
combination of industry expertise and auditing expertise within audit committees in improving internal audit (IA). Hence, the study adds to two areas within the literature, these being: a) the effectiveness of audit committees as determined by characteristics other than audit expertise (Krishnan et al., 2011; Carcello \& Neal, 2003); b) and the relationship between audit committee and IA (Abbott et al., 2010; Barua et al., 2010; Callahan \& Soileau, 2010; Mat Zain et al., 2006; Goodwin-Stewart \& Kent, 2006; Goodwin, 2003).

Consistent with prior research (Lenz et al., 2014; Abbott et al., 2012; Sarens, 2009; Goodwin-Stewart \& Kent, 2006; Carcello et al., 2005; Van Peursem, 2005), two measures are used as proxies of the IAC including: size of IA and budget of IA. To examine the impact of audit committee industry expertise on IAC, a sample of 64 (39\%) questionnaires which were sent to chief internal auditors (CIA) in Saudi companies listed in the Saudi Stock Exchange TADAWL in 2014.

It is defined that an audit committee member have industry expertise if $\mathrm{s} / \mathrm{he}$ is currently or has previously been employed by another firm in the same industry as the one in which s/he now serves as an audit commitee member. Our results indicate that audit committees with members who are both industry and auditing experts consistently have more influence on the IA than those with auditing experts alone. Also, audit committees with members who are industry experts and meet more frequently have more influence on IA. Overall, our results suggest that in order to more effectively monitor IA, it is beneficial for audit committee members to have industry expertise in addition to auditing expertise.

\section{Prior Research and Hypotheses Development}

It is necessary for the relevant business environment and industry to be taken into account when preparing financial statements on behalf of companies, since within those statements certain estimates must be made (CIFR, 2008), and consequently, the possession of industry expertise will assist audit committees in their appreciation and evaluation of industry-specific issues. Such knowledge of the industry concerned is vital if those estimates are to be made accurately and completely. Indeed, this is acknowledged by the International Professional Practice Framework (IPPF) (IIA, 2012), which encourages internal auditors to engage in continuing professional education (CPE) concerned with the business of their organisations such that they can remain proficient in their ability to contribute towards the governance, risk, and control processes in which they are involved.

Research suggests that auditors with industry-specific knowledge are more likely to possess a comprehensive understanding of a company's characteristics, which enhances their capacity to detect errors (Maletta \& Wright, 1996; Owhoso et al., 2002), and generally enhance their reporting ability (see, e.g., Reichelt \& Wang, 2010; Romanus et al., 2008; Dunn \& Mayhew, 2004; DeFond et al., 2000). Additionally, Dunn and Mayhew (2004) found that financial analysts ranked companies with industry-specialist auditors as having higher disclosure quality than companies with non-specialist auditors.

It is clear therefore, that auditing experts can become more valuable if they also possess industry expertise since this equips them with the ability to grasp the nuances of internal auditing that are particular to the industry in which their company operates. Consequently, the possession of industry-specific business knowledge can promote better IAC (Barua et al., 2010; Mat Zain et al., 2006; Carcello et al., 2005). Further, since the presence of audit committee knowledge in accounting and auditing has an impact on IAC (Alzeban \& Sawan, 2015; Barua et al., 2010; Mat Zain et al., 2006; Carcello et al., 2005), it is reasonable to expect that audit committee industry expertise will do the same. It is thus predicted that audit committees with industry expertise are more likely to demonstrate a thorough appreciation of a company's characteristics, and hence require more depth and scope in respect of the activities of internal audit. In turn, this should improve IAC. Moreover, audit committees with industry knowledge will better understand the particular problems facing their companies. Consequently, it can be seen that audit committee industry expertise will generate improved monitoring capabilities, and all-round advantages. It is arguable that the presence of audit committee industry expertise along with auditing expertise, results in greater investment in internal audit resources, thereby enabling the internal audit department function effectively. Hence, the following hypothesis is formulated:

H1: When audit committee members possess industry expertise as well as auditing expertise the committee is more effective than when the members possess auditing expertise alone.

\subsection{Internal Audit Characteristics (IAC)}

Internal audit characteristics (IAC) determine the degree to which an internal audit unit can operate effectively, and one important characteristic relates to the level of resourcing allocated to the internal audit function, and by implication, the size of the unit. In this respect, Al-Twaijry et al. (2004) found that when questioning Saudi Arabian internal and external auditors, via a survey and interview approach, external auditors considered that the 
quality of the internal audit function was directly related to its size. It was noted that staff rotation was facilitated in large units since their size provided them with flexibility. Other important characteristics have been identified by researchers, such as Alzeban and Sawan (2015), Barua et al. (2010), Mat Zain et al. (2006), and Carcello et al. (2005) who suggest significant associations between the allocated resources and size of internal audit and the independence of audit committee and presence of member's expertise.

\section{Research Method}

The research design involved the use of a questionnaire survey. The purpose was to identify and quantify a measure of IAC and regress this against AC industry expertise. Consistent with much prior internal audit research (e.g. Abbott et al., 2012; Abbott et al., 2010; Mat Zain et al., 2006; Carcello et al., 2005; Raghunandan et al., 2001) the survey was sent to chief internal auditors (CIAs). In total, 159 questionnaires were sent to the CIAs of all Saudi companies listed on the Saudi Stock Exchange TADAWL in 2014, and from this distribution, 64 questionnaires were returned, giving a response rate of $39 \%$, which is considered good in comparison with the rates achieved in other research. Goodwin-Stewart and Kent (2006), for instance, in their study of external audit fees, audit committees characteristics and internal audit, obtained a response rate of $35 \%$ when targeting companies listed in Australian Stock Exchange; and a study conducted by Abbott et al. (2012) in the US, focusing on the the impact of internal audit organizational oversight status on the reduction of external audit fees, realized a response rate of $16.7 \%$.

The main aim of this study is to explore the impact of audit committee industry expertise on the IAC. Several measures were used as proxies for the IAC, including: size of IA, and budget allocated to internal audit. This strategy was in keeping with that adopted by previous researchers (see, e.g. Lenz et al., 2014; Abbott et al., 2012; Sarens, 2009; Goodwin-Stewart \& Kent, 2006; Carcello et al., 2005; Van Peursem, 2005). In creating measure of industry expertise, it is defined that an audit committee member with such expertise as one who is currently or has previously been employed by another firm in the same industry as the one in which s/he now serves as an audit committee member.

Instruments used with success in previous research were used as the basis for formulating the questions in the survey, as recommended by Bryman and Bell (2007). The questionnaire was designed to obtain the perceptions of IAC and audit committee industry expertise, and it comprised four sections. Section A required respondents to provide general information about themselves and IAC; section B was concerned with assessing audit committee characteristics and industry expertise; section $\mathrm{C}$ asked respondents to provide information on the interaction between internal audit and the audit committee; and section $\mathrm{D}$ focused on the extent of management support for internal audit.

\subsection{Model}

Again consistent with prior research (e.g. Alzeban \& Sawan, 2015; Abbott et al., 2010; Reichelt \& Wang, 2010; Mat Zain et al., 2006; Carcello et al., 2005), the following OLS regression equation is estimated to examine the impact of audit committee industry expertise on IAC:

$$
\begin{gathered}
I A C=B_{0}+B_{1} \text { SUPPORT }+B_{2} \text { SIZE }+B_{3} \text { TENURE }+B_{4} \text { INDEPENDENCE }+B_{5} \text { EXPERTISE }+B_{6} \text { MEETING }+ \\
B_{7} \text { INDUSTRY }+B_{8} \text { INDUSTRYAUDIT }+E_{i}
\end{gathered}
$$

Where:

IAC=Internal audit characteristics (size of IA equals to natural $\log$ of the total number of staff in the IA department divided by the natural log of total assets, and budget of IA equals to natural log of the IA budget).

SUPPORT=Management support for internal audit $(1=$ strongly disagree to $5=$ strongly agree $)$.

SIZE=Firm size (natural log of total assets).

TENURE $=$ The number of years the audit committee member has been in his/her position.

INDEPENDENCE $=1$ if audit committee is $100 \%$ independent, else 0 .

EXPERTISE $=1$ if audit committee has at least one auditing expert, else 0.

MEETING=The frequency of audit committee meetings.

INDUSTRY=Audit committee members who are only industry experts and not audit experts.

INDUSTRYAUDIT=Audit committee members who are industry experts and also audit experts.

The control variables are arrived at having considered the work of researchers (Alzeban \& Gwilliam, 2014; Cohen \& Sayag, 2010; Mihret \& Yismaw, 2007), who have concluded a positive and significant relationship 
between management support and IAC, and researchers (Sarens \& Abdolmohammadi, 2011; Barua et al., 2010; Goodwin-Stewart \& Kent, 2006; Carcello et al., 2005) who find a positive and significant relationship between firm size and IAC, and firm size and internal audit budget. The hypotheses are tested using OLS. A multiple regression was performed between IAC as the dependent variable and the independent variable (audit committee industry expertise).

\section{Results}

Table 1 presents descriptive statistics for 64 firms. The results indicate that on average, audit committees have 8\% of their membership who are both auditing and industry experts. It is noted that those industry experts (not tabulated) exist in one industry only, that being banks and financial. The results also show that on average audit committees have only $14 \%$ of their membership with industrial expertise. These experts come from three industries: banks and financial, petrochemical, and insurance. In addition, $51 \%$ of audit committees have no representation among their membership whatsoever of individuals with anything other than auditing expertise. This is a pattern that is not entirely unexpected given the developing nature of internal auditing in Saudi Arabia, and the fact that it is known that audit committees are criticised for their lack of effectiveness (Alruhaily, 2008; Al-Twaijry et al., 2002).

Table 1. Descriptive statistics

\begin{tabular}{lllll}
\hline Variables & Minimum & Maximum & Mean & S.D. \\
\hline Iacsize & 1 & 35 & 7.4 & 6.8 \\
Iacbudget (Millions $\$$ ) & 0.01 & 2 & .62 & 1.4 \\
Support & 1 & 5 & 3.6 & .74 \\
Size (Billions $\$$ ) & 0.13 & 90.4 & 6.3 & 1.2 \\
Tenure & .9 & 3 & 1.7 & .67 \\
Independence & 0 & 1 & .85 & .34 \\
Expertise & 0 & 1 & .51 & .52 \\
Meeting & 1 & 6 & 4.3 & 1.2 \\
Industry & 0 & 1 & .14 & .38 \\
Industryaudit & 0 & 1 & .08 & .27 \\
\hline
\end{tabular}

Table 2 presents the results of the correlation matrix for the dependent, independent, and control variables included in this study. The correlation results reveal significant association $(\mathrm{p}<.01)$ between audit committee members who are industry experts and also audit experts (Industry Audit) and IAC (size IAC size and budget IAC budget), whereas no association is demonstrated between audit committee members who are only industry experts (INDUSTRY) and IAC $\mathrm{p}>.05$. Further, the results suggest a significant relationship $(\mathrm{p}<.01)$ between IAC (IACSIZE and IACBUDGET) and the other six variables (Support, Size, Tenure, Independence, Expertise, Meeting) $\mathrm{p}<.01$ - giving a result which is consistent with prior studies (e.g., Alzeban \& Sawan, 2015; Abbott et al., 2012; Barua et al., 2010; Naiker \& Sharma, 2009; Raghunandan \& Rama, 2007; Mat Zain et al., 2006; Goodwin-Stewart \& Kent, 2006; Raghunandan et al., 2001).

Table 2. Pearson correlation coefficients for the variables

\begin{tabular}{|c|c|c|c|c|c|c|c|c|c|c|}
\hline & 1 & 2 & 3 & 4 & 5 & 6 & 7 & 8 & 9 & 10 \\
\hline 1 Iac size & 1.00 & & & & & & & & & \\
\hline 2 Iac budget & $.51 * *$ & 1.00 & & & & & & & & \\
\hline 3 Support & $.58 * *$ & $.54 * *$ & 1.00 & & & & & & & \\
\hline 4 Size & $.56 * *$ & $.51 * *$ & $.37 * *$ & 1.00 & & & & & & \\
\hline 5 Tenure & $.45 * *$ & $.39 * *$ & $.33 * *$ & $.46^{* *}$ & 1.00 & & & & & \\
\hline 6 Independence & $.47 * *$ & $.42 * *$ & $.23 *$ & $.38 * *$ & $.31 *$ & 1.00 & & & & \\
\hline 7 Expertise & $.44 * *$ & $.28^{*}$ & .21 & $.27^{*}$ & .21 & $.22 *$ & 1.00 & & & \\
\hline 8 Meeting & $.33 * *$ & $.46 * *$ & .18 & .21 & $.26^{*}$ & $.34 * *$ & $.23 *$ & 1.00 & & \\
\hline 9 Industry & .12 & .09 & .15 & $.37 * *$ & .16 & .01 & $.27 *$ & .16 & 1.00 & \\
\hline 10 Industry audit & $.57 * *$ & $.52 * *$ & $.43 * *$ & $.49 * *$ & $.37 * *$ & $.24 *$ & $.36 * *$ & .19 & $.26^{*}$ & 1.00 \\
\hline
\end{tabular}

Note. $*$ Correlation is significant at the 0.05 level; $* *$ Correlation is significant at the 0.01 level. 
Table 3 presents the results for the testing of $\mathrm{H} 1$. The model is tested for two dependent variables, IAC Size and IAC Budget.

\subsection{IAC Size}

Firstly, the regression results of the first model (IAC Size as dependent variable) shows that the overall model is significant at $\mathrm{p}<.01$, with an adjusted $\mathrm{R}^{2}$ of .42 . The coefficients on the control variables (Support, Size, and Tenure) are significant $\mathrm{p}<.01$. For testing the variables, the coefficient on Industry Audit shows a significant positive association $\mathrm{p}<.01$ (supporting H1) suggesting that the presence of audit committee industry expertise, when combined with auditing expertise, can promote an increased size of internal audit. Further, the regression results suggest that Industry Audit, among the other variables, contributed the most to IAC Size $(\beta=.444)$. Moreover, the findings indicate that audit committees whose members who are auditing experts only (Expertise) are significantly associated with IAC Size $(\mathrm{p}<.05)$, whereas there is no association between IAC Size and audit committee members who are only industry experts (Industry) $p>.05$ - suggesting that audit committee members who are industry experts and also audit experts have a greater influence on IAC Size than Audit Experts alone.

Table 3. Regression results

\begin{tabular}{lllllll}
\hline & \multicolumn{3}{c}{$\begin{array}{c}\text { Model 1 } \\
\text { IAC Size }\end{array}$} & \multicolumn{3}{c}{$\begin{array}{c}\text { Model 2 } \\
\text { IAC Budget }\end{array}$} \\
\hline Variable & $\beta$. & $\mathrm{t}$ & Sig. & $\beta$. & $\mathrm{t}$ & Sig. \\
\hline Support & .475 & 5.235 & .000 & .351 & 3.578 & .001 \\
Size & .293 & 2.981 & .004 & .318 & 3.070 & .003 \\
Tenure & .232 & 2.700 & .009 & .272 & 2.420 & .019 \\
Independence & .286 & 2.885 & .005 & .307 & 2.696 & .009 \\
Expertise & .264 & 2.382 & .020 & .272 & 2.130 & .037 \\
Meeting & .233 & 2.172 & .034 & .343 & 2.880 & .006 \\
Industry & .195 & 1.983 & .052 & .120 & 1.087 & .282 \\
Industry Audit & .444 & 3.014 & .001 & .456 & 3.250 & .002 \\
$\mathrm{R}^{2}=.45$ & & & & $\mathrm{R}^{2}=.57$ & & \\
Adjusted $\mathrm{R}^{2}=.42$ & & & & Adjusted $\mathrm{R}^{2}=.55$ & \\
$\mathrm{~F}=16.281$ & & & $\mathrm{~F}=26.940$ & \\
$\mathrm{P}<.01$ & & & $\mathrm{P}<.01$ & \\
\hline
\end{tabular}

\subsection{IAC Budget}

Secondly, the regression results of the second model (IAC Budget as dependent variable) show that the overall model is also significant at $\mathrm{p}<.01$, with an adjusted $\mathrm{R}^{2}$ of .55 . The coefficients on the control variables are significant (Support and Size $\mathrm{p}<.01$; and Tenure $\mathrm{p}<.05$ ). For testing the variables, the coefficient on Industry Audit shows a significant positive association $\mathrm{p}<.01$ (also supporting H1) suggesting that the presence of audit committee members with industry expertise, when combined with auditing expertise, can promote the budget of internal audit. Further, the regression results suggest that Industry Audit, among the other variables, contributed the most to IAC Budget $(\beta=.456)$. Moreover, the findings indicate that audit committee member with auditing-only experts (Expertise) are significantly associated with IAC Budget $(\mathrm{p}<.05)$, whereas the findings show no association between IAC Budget and audit committee members who are only industry experts (Industry) $\mathrm{p}>.05$-suggesting that audit committee members who are industry experts and also audit experts have a greater influence on IAC Budget than audit experts alone.

Overall, both models are significant, indicating that audit committee members with both industry and audit expertise, increase effective IAC. Our results support those of Mat Zain et al. (2006), who discovered that a greater contribution to financial reporting is made by internal auditors in circumstances where the audit committee is more effective (in terms of independence and auditing experts), and who also found a positive association between internal auditors' evaluation of their contribution to the financial statement audit and IACs, including size of internal audit. Hence, it can be argued that the more effective the audit committee (in terms of industry expertise combined with auditing experts), the greater the IACs (in terms of a well-resourced internal audit), and the more able are the internal auditors to contribute to financial reporting. Further, the findings of this study provide support to the study of Alzeban and Sawan (2015) who found significant association between audit committee characteristics and the implementation of internal audit recommendations. Hence, it is arguable that 
audit committee members who are industry experts and also audit experts have greater influence on the implementation of internal audit recommendations.

\section{Conclusion}

The objective of this study was to examine the impact of audit committee industry expertise on the internal audit characteristics (IAC). It is concluded from the large corpus of literature that IAC, and the quality of financial reporting, is influenced for the better by the presence of audit committee independence, and auditing expertise. However, an area of expertise on which the regulators have remained silent, is that pertaining to industry knowledge and experience, despite the very valid question that can be raised about whether such expertise on the audit committee would improve the committee's ability to promote IAC. By investigating this question, this study fills a void in the literature.

The findings indicate that audit committee members who are both industry and auditing experts have greater influence on IAC than members who have only auditing expertise. These findings provide support for the empirical evidence gathered by prior studies (Alzeban \& Sawan, 2015; Cohen et al., 2014; Abbott et al., 2012; Abbott et al., 2010; Barua et al., 2010; Goodwin-Stewart \& Kent, 2006; Mat Zain et al., 2006). They offer empirical evidence to support the outcomes reported by Mat Zain et al. (2006) concerning audit committee characteristics and internal auditors' assessment of their contribution to financial statement audits, to the effect that a greater contribution to the external audit is made by internal auditors when audit committee members are independent. Consequently, it can be argued that the presence of audit committee industry expertise combined with auditing expertise has a very substantial influence on IAC, and thus, allows for a greater contribution from internal auditors to external audit.

The findings of this study have practical implications in as much as they show the worth of audit committee members who possess both auditing and industry expertise. Such individuals enhance the overall effectiveness of the audit committee and IAC, and consequently, firms should seek to appoint members to the audit committee who can demonstrate both types of expertise. Moreover, standard setters and regulators would do well to give thought to the matter of industry expertise, and if convinced by empirical findings in this area, make recommendations about the qualifications required of individuals before they can be considered for audit committee membership.

As a last comment, it is appropriate to consider the potential for generalising the results of the study to other contexts, since the study itself was performed in one specific country which possesses a number of quite unique features. These features include a very rapid developmental trajectory, and the swift establishment of both public and private economic entities which are likely to benefit from internal audit units, and the presence of audit committees. Additionally, however, unlike the vast majority of developing countries, Saudi Arabia is extremely rich, entirely because of its massive and easily extractable oil reserves. Furthermore, the country has very specific characteristics in respect of cultural traditions, custom, and social structure. So, whether the study's findings can be easily generalised to other developing countries which do not have access to almost unlimited oil reserves, or to developed countries with a much longer tradition of commercial enterprise, and forms of governance within those entities, is an issue for consideration. In response, it can be said that in developing environments which have only recently taken on the idea of audit committees in whatever form that might take, and where similarities exist in society and culture but which differ from what prevails in developed countries where traditions are different, and there is a longer history of more formalised governance, then it is even more probable that the outcomes can be generalised. However, given the early stage of this type of research, more inquiry is required to establish the validity of these claims, and the recommendation is made that additional studies are performed in both developing and developed countries and, to some extent, in the private sector.

\section{References}

Abbott, L., Parker, S., \& Peters, G. (2010). Serving two masters: The association between audit committee internal audit oversight and internal audit activities. Accounting Horizons, 24(1), 1-24. http://dx.doi.org/10.2308/acch.2010.24.1.1

Abbott, L., Parker, S., \& Peters, G. (2012). Audit fee reductions from internal audit-provided assistance: The incremental impact of internal audit characteristics. Contemporary Accounting Research, 29(1), 94-118. http://dx.doi.org/10.1111/j.1911-3846.2011.01072.x

Abbott, L., Parker, S., Peters, G., \& Raghunandan, K. (2003). An empirical investigation of audit fees, nonaudit fees and audit committees. Contemporary Accounting Research, 20(2), 215-234. http://dx.doi.org/10.1506/8YP9-P27G-5NW5-DJKK 
Alruhaily, A. (2008). Audit committees as one of the pillars of corporate governance: The case of Saudi Arabia. King Abdulaziz University Journal, College of Business and Economic, 22(1), 179-218. http://dx.doi.org/10.4197/Eco.22-1.4

Al-Twaijry, A., Brierley, J., \& Gwilliam, D. (2004). An examination of the relationship between internal and external audit in the Saudi Arabian corporate sector. Managerial Auditing Journal, 19(7), 929-944. http://dx.doi.org/10.1108/02686900410549448

Al-Twaijry, A., Brierley, J., \& Gwilliam, D. (2002). An examination of the role of audit committees in the Saudi $\begin{array}{lllll}\text { Arabian corporate } & \text { sector. } & \text { Corporate } & \text { Governance, } & 10(4),\end{array}$ http://dx.doi.org/10.1111/1467-8683.00293

Alzeban, A., \& Gwilliam, D. (2014). Factors affecting the internal audit effectiveness: A survey of the Saudi public sector. Journal of International Accounting, Auditing and Taxation, 23(2), 74-86. http://dx.doi.org/10.1016/j.intaccaudtax.2014.06.001

Alzeban, A., \& Sawan, N. (2015). The impact of audit committee characteristics on the implementation of internal audit recommendation. Journal of International Accounting, Auditing and Taxation (forthcoming).

Balsam, S., Krishnan, J., \& Yang, J. (2003). Auditor industry specialization and earnings quality. Auditing: A Journal of Practice \& Theory, 22(2), 71-97. http://dx.doi.org/10.2308/aud.2003.22.2.71

Barua, A., Rama, D., \& Sharma, V. (2010). Audit committee characteristics and investment in internal auditing. Journal of Accounting and Public Policy, 29, 503-513. http://dx.doi.org/10.1016/j.jaccpubpol.2010.09.001

Beasley, M., Carcello, J., Hermanson, D., \& Lapides, P. (2000). Fraudulent financial reporting: Consideration of industry traits and corporate governance mechanisms. Accounting Horizons, 14(4), 441-454. http://dx.doi.org/10.2308/acch.2000.14.4.441

Beasley, M., Carcello, J., Hermanson, D., \& Neal, T. (2010). Fraudulent Financial Reporting: 1998-2007: An Analysis of U.S. Public Companies. Durham, NC: COSO.

Bédard, J., \& Gendron, Y. Y. (2010). Strengthening the financial reporting system: Can audit committees deliver? International Journal of Auditing, 14(2), 174-210.

Bryman, A., \& Bell, E. (2007). Business research methods (2nd ed.). The US: Oxford University Press Inc.

Callahan, C., \& Soileau, J. (2010, July-August). Influence of audit committee and internal audit function effectiveness on enterprise risk management adoption. American Accounting Association Annual Meeting and Conference on Teaching and Learning in Accounting. San Francisco: The US. Retrieved from http://aaahq.org/MARegion/2010/2010MA_Abstracts/10-049-PAPER.pdf

Carcello, J., \& Neal, T. (2003). Audit committee characteristics and auditor dismissals following "new" going concern reports. The Accounting Review, 78(1), 453-468. http://dx.doi.org/10.2308/accr.2003.78.1.95

Carcello, J., Hermanson, D., \& Raghunandan, K. (2005). Factors associated with US public companies' investment in internal auditing. Accounting Horizons, 19(2), 65-80. http://dx.doi.org/10.2308/acch.2005.19.2.69

Carcello, J., Hermanson, D., \& Ye, Z. (2011b). Corporate governance research in accounting and auditing: Insights, practice implications, and future research directions. Auditing: A Journal of Practice \& Theory, $30(3), 1-31$.

Carcello, J., Hermanson, D., Neal, T., \& Riley, R. (2002). Board characteristics and audit fees. Contemporary Accounting Research, 19(3), 365-384. http://dx.doi.org/10.1506/CHWK-GMQ0-MLKE-K03V

Carcello, J., Neal, T., Palmrose, Z. V., \& Scholz, S. (2011a). CEO involvement in selecting board members, audit committee effectiveness, and restatements. Contemporary Accounting Research, 28(2), 396-430. http://dx.doi.org/10.1111/j.1911-3846.2010.01052.x

Centre for International Finance and Regulation (CIFR). (2008). Final Report of the Advisory Committee on Improvements to Financial Reporting to the U.S (August). Washington, DC: SEC.

Cohen, A., \& Sayag, G. (2010). The effectiveness of internal auditing: an empirical examination of its determinants in Israeli organisations. Australian Accounting Review, 20(3), 296-307. http://dx.doi.org/10.1111/j.1835-2561.2010.00092.x

Cohen, J., Hoitash, U., \& Wright, A. (2014). The effect of audit committee industry expertise on monitoring the financial reporting process. The Accounting Review, 89(1), 243-273. http://dx.doi.org/10.2308/accr-50585 
Cohen, J., Krishnamoorthy, G., \& Wright, A. (2004). The corporate governance mosaic and financial reporting quality. Journal of Accounting Literature, 23, 87-152.

Deloitte Development. (2010). Audit committee composition. Audit Committee Brief (June).

DeFond, M., Francis, J., \& Wong, T. (2000). Auditor industry specialization and market segmentation: Evidence from Hong Kong. Auditing: A Journal of Practice \& Theory, 19(1), 49-66. http://dx.doi.org/10.2308/aud.2000.19.1.49

DeZoort, F., Hermanson, D., Archambeault, D., \& Reed, S. (2002). Audit committee effectiveness: A synthesis of the empirical audit committee literature. Journal of Accounting Literature, 21, 38-75.

Dhaliwal, D., Naiker, V., \& Navissi, F. (2010). The association between accruals quality and the characteristics of accounting experts and mix of expertise on audit committees. Contemporary Accounting Research, 27(3), 787-827. http://dx.doi.org/10.1111/j.1911-3846.2010.01027.x

Dunn, K., \& Mayhew, B. (2004). Audit firm industry specialization and client disclosure quality. Review of Accounting Studies, 9(1), 35-58. http://dx.doi.org/10.1023/B:RAST.0000013628.49401.69

Francis, J., LaFond, R., Olsson, P., \& Schipper, K. (2004). Cost of capital and earnings attributes. The Accounting Review, 79(4), 967-1010. http://dx.doi.org/10.2308/accr.2004.79.4.967

Goodwin, J. (2003). The relationship between the audit committee and the internal audit function: Evidence from Australia and New Zealand. International Journal of Auditing, 7, 263-278. http://dx.doi.org/10.1046/j.1099-1123.2003.00074.x

Goodwin-Stewart, J., \& Kent, P. (2006). The relation between external audit fees, audit committee characteristics $\begin{array}{llll}\text { and internal audit. Accounting and } & \text { Finance, 467-404. }\end{array}$ http://dx.doi.org/10.1111/j.1467-629X.2006.00174.x

Hoitash, R., \& Hoitash, U. (2009). The role of audit committees in managing relationships with external auditors after SOX. Managerial Auditing Journal, 24(4), 368-397. http://dx.doi.org/10.1108/02686900910948206

Institute of Internal Auditors (IIA). (2012). International Standards for the Professional Practice of Internal Auditing. $\quad$ Florida: The IIA. $\quad$ Retrieved from https://na.theiia.org/standards-guidance/mandatory-guidance/Pages/Standards.aspx

Krishnan, G., \& Visvanathan, G. (2008). Does the SOX definition of an accounting expert matter? The association between audit committee directors accounting expertise and accounting conservatism. Contemporary Accounting Research, 25(3), 827-858. http://dx.doi.org/10.1506/car.25.3.7

Krishnan, J., Wen, Y., \& Zhao, W. (2011). Legal expertise on corporate audit committees and financial reporting quality. The Accounting Review, 86(6), 2099-2130. http://dx.doi.org/10.2308/accr-10135

Lenz, R., Sarens, G., \& D'Silva, K. (2014). Probing the discriminatory power of characteristics of internal audit functions: sorting the wheat from the chaff. International Journal of Auditing, 18(2), 126-138. http://dx.doi.org/10.1111/ijau.12017

Maletta, M., \& Wright, A. (1996). Audit evidence planning: An examination of industry error characteristics. Auditing: A Journal of Practice \& Theory, 15(1), 71-86.

Mat Zain, M., Subramaniam, N., \& Stewart, J. (2006). Internal auditors' assessment of their contribution to financial statement audits: the relationship with audit committee and internal audit function characteristics. International Journal of Auditing, 18(1), 1-18. http://dx.doi.org/10.1111/j.1099-1123.2006.00306.x

Mihret, D., \& Yismaw, A. (2007). Internal audit effectiveness: An Ethiopian public sector case study. Managerial Auditing Journal, 22(5), 470-484. http://dx.doi.org/10.1108/02686900710750757

Moroney, R. (2007). Does industry expertise improve the efficiency of audit judgment? Auditing: A Journal of Practice \& Theory, 27(2), 69-94.

Naiker, V., Sharma, D., \& Sharma, V. (2013). Do former audit firm partners on audit committees procure greater nonaudit services from the auditor? The Accounting Review, 88(1), 297-326. http://dx.doi.org/10.2308/accr-50271

Olson, J. (1999). How to really make audit committees more effective. Business Lawyer, 54(May), 1097-1111.

Owhoso, V. Messier, W., \& Lynch, J. (2002). Error detection by industry-specialized teams during sequential audit review. Journal of Accounting Research, 40(3), 883-900. http://dx.doi.org/10.1111/1475-679X.00075 
Raghunandan, K., \& Rama, D. (2007). Determinants of audit committee diligence. Accounting Horizons, 21(3), 265-280. http://dx.doi.org/10.2308/acch.2007.21.3.265

Raghunandan, K., Read, W., \& Rama, V. (2001). Audit committee composition, “Gray director”, and interaction with internal auditing. Accounting Horizons, 15(2), 105-118. http://dx.doi.org/10.2308/acch.2001.15.2.105

Reichelt, K., \& Wang, D. (2010). National and office-specific measures of auditor industry expertise and effects on audit quality. Journal of Accounting Research, 48(3), 647-686. http://dx.doi.org/10.1111/j.1475-679X.2009.00363.x

Romanus, R., Maher, J., \& Fleming, D. (2008). Auditor industry specialization, auditor changes and accounting restatements. Accounting Horizons, 22(4), 389-413. http://dx.doi.org/10.2308/acch.2008.22.4.389

Sarens, G. (2009). Internal auditing research: Where are we going? Editorial. International Journal of Auditing, 13(1), 1-7. http://dx.doi.org/10.1111/j.1099-1123.2008.00387.x

Sarens, G., \& Abdolmohammadi, M. (2011). Monitoring effects of the internal audit function: Agency theory versus other explanatory variables. International Journal of Auditing, 15(1), 1-20. http://dx.doi.org/10.1111/j.1099-1123.2010.00419.x

Stewart, J., \& Kent, P. (2006). Relation between external audit fees, audit committee characteristics and internal audit. Accounting and Finance, 46(3), 387-404. http://dx.doi.org/10.1111/j.1467-629X.2006.00174.x

Van Peursem, K. (2005). Conversations with internal auditors: The power of ambiguity. Managerial Auditing Journal, 20(5), 489-512. http://dx.doi.org/10.1108/02686900510598849

\section{Copyrights}

Copyright for this article is retained by the author(s), with first publication rights granted to the journal.

This is an open-access article distributed under the terms and conditions of the Creative Commons Attribution license (http://creativecommons.org/licenses/by/3.0/). 